and retiring, but when he thought it necessary he could be forthright in expressing bis views in public and he could fight hard for what he felt to be right. Both his personal and intellectual qualities gained him an international reputation.

R. T. GRant

\section{Prof. D. E. White}

Prof. D. E. White, who held the chair of organic chemistry in the University of Western Australia, died following a car accident on April 4 at the age of fifty-three.

White was born in New South Wales in 1910 and was educated at Parramatta High School. He attended the University of Sydney from 1927 until 1934, and after graduating with first-class honours he worked with Prof. V.M. Trikojus on essential oils to obtain his M.Sc. He was awarded a D.Phil. at Oxford in 1934 for his research with Sir Robert Robinson on the mould metabolite pigment ravanelin. After two years with Imperial Chernical Industries he returned to the University of Sydney as tutor in chemistry at St. Andrews College. In 1940 he transferred to the School of Public Health and Tropical Medicine as a biochemist, moving in the following year to a position of lecturer in organic chemistry at the University of Melbourne. In 1943 he began a long association with the University of Western Australia as lecturer in charge of organic chemistry. He was soon promoted to senior lecturer and then to reader and head of the department of organic chemistry. In 1958, White became the University's first professor of organic chemistry. During 1962-63, he held the South-east Asia Treaty Organization chair of organic chemistry at the University of Medical Sciences, Bankok.

White's research career covered most of the field of plant chemistry. Soon after he arrived at Perth he was associated with the Drug Panel of the Department of Industrial Development, seeking to obtain essential drugs from local plants. Although nothing economic came from this work, it initiated his extensive research on Western Australian plants. The many important articles which followed dealt with anthocyanins, coumarins, alkaloids, tannins, essential oils and the polyterpenes. His achievements were not always purely academic; thus in 1950 he began work on the infertility of ewes pastured on subterranean clover, leading to the isolation and identification of the ostrogenic isoflavones formononetin and genistein.

He was abroad on study leave in 1950-51 when he attended the Universities of Oxford and Stockholm and the Technical High School, Zurich. His experiences in Switzerland, working with Jeger on lanosterol, prompted him to adopt the polyterpenes as a speciality, and most of his later work was with complex terpenes, particularly those from Pittosporum, Melaleuca and Beyeria spp. During 1960-61 he spent a sabbatical year at the University of California, Los Angeles, and at Stanford.

While in Western Australia, Prof. White saw a great expansion of the University and it was largely due to him that the role of organic chemistry expanded in pro. portion. He quickly recognized advances in his science and actively sought adequate staff and equipment to exploit these advances. His quiet manner and modesty about his own achievements concealed a perceptive energetic mind which was greatly valued by his associates. His generous nature was evident in every way. Besides his research interests, he took an important part in the administration and teaching of his University, serving on many University committees and as Dean of the Faculty of Science from 1957 until 1959.

He had a deep feeling for the value of scientific societies and freely gave his time for their advancement. He had long associations with the committees of the Royal Australian Chemical Institute, the Australian and New Zealand Association for the Advancement of Science and the Royal Society of Western Australia.
White was a student of languages and a keen amateur botanist. He always collected his own plant material for research, and many overseas visitors will recall the pleasure he gained in conducting tours of the wild-flower districts.

$\mathrm{He}$ was devoted to his wife and two daughters, who survive him.

P. R. JEFFERIES

\section{Prof. Victor van Straelen}

THe sudden death of Prof. V. van Straelen in Brussels on February 29 is a great loss, not only to Belgium but also to all organizations concerned with the conservation of nature and the development of nature reserves and national parks. $\mathrm{He}$ was born at A.ntwerp on June 14, 1889 , and his scientific work, mainly as a distinguished palæontologist, was dealt with in Nature of September 3, 1955, on the occasion of his retirement in 1954 from his post as director of the Institut royal des Sciences naturelles de Belgique which he had occupied for twenty-eight years. At a ceremony of "Manifestation d'Hommage" held in his honour shortly afterwards, he was presented with two Volumes Jubilaires containing contributions from his scientific staff.

In his later years he devoted most of his energy to Nature protection and was largely responsible for the foundation of the great national parks in the Belgian Congo. Ho made numerous visits to the (former) Belgian territories in Africa, often accompanied by his wife, a distinguished botanist, and was responsible for the organization of numerous exploring expeditions to those regions.

It is possible here to refer to only a few of his many activities. $\mathrm{He}$ founded: in 1943 the Association pour l'Etude de la Paleontologie et la Stratigraphie Houillières, which has published 36 memoirs; in 1946 l'A.ssociation pour les Etudes texturales; in 1950 le Comité pour l'Elaboration de la Carte des Sols et de la Vegetation de Belgique, resulting in the production of 150 charts covering three-quarters of the territory. $\mathrm{He}$ organized in 1946 the hydro-biological exploration of Lake Tanganyika, the results of which were published in four volumes. This work was extended during 1952-54 to include investigations of Lakes Kivu, Edward and Albert, and five fascicules dealing with the results have appeared. In addition, he was president, vice-president or member of council of a great variety of scientific institutions: l'Institut des Pares Nationaux au Congo, one of his great achievements, in which he organized their systematic exploration and conservation; l'Institut maritime d'Ostende; le Comité scientifique de l'Institut de Sociologie Ernest Solvay; l'Association internationale pour la Protection de la Nature; IRSAC; IRSIA.; la Comité de l'Exploration Antaretique belge de la Belgica; le Fonds national de la Recherche scientifique; le Comité national des Sciences biologiques; Ie Conseil géologique de Belgique; la Commission de Géologie du Ministre des Colonies; le Syndicat pour l'Etude minière et géologique de la Cuvette centrale congolaise; le Conseil de Surveillance de la Bibliotheque royale; la Commission permanente de la Chasse et de la Pêche; le Conseil supérieur des Forêts; la Commission royale des Monuments et des Sites; in addition to many national scientific societies.

He was elected a Membre correspondant of the Belgian Royal A.cademy in 1931 and in 1955 became Membre titulaire; ho was also Membre de l'Académie royale des Sciences d'Outre-Mer. He received numerous honours from other countries, including docteur honoris causa of the University of Caen. He was a foreign member of la Société géologique de France; l'A.cadémie Colombienne de Ciencias Exactas Fisico-Quimicos y naturales a Bogota; the Koninglyk Nederlands Aardrijkskundig Genootschap d'Amsterdam, the Linnean Society of London, the Zoological Society of London and the Geological Society of London. 